Review Article

www.ijrap.net

\title{
OVERVIEW OF FOLK MEDICINE USED FOR TYPHOID IN INDIA
}

\author{
Sharad Maroti Porte*
}

Lecturer, National Institute of Ayurveda, Madhav Vilas Palace, Amer Road, Jaipur, India

Received on: 23/12/13 Revised on: 15/01/14 Accepted on: 02/03/14

\begin{abstract}
*Corresponding author
Dr. Sharad M. Porte, M.D. (Ayu.), Lecturer, P.G. Dept. of Agad Tantra, National Institute of Ayurveda, Madhav Vilas Palace, Near Joravar Singh Gate, Amer Road, Jaipur 302002 Rajasthan, India E-mail: portesmdr@gmail.com

DOI: $10.7897 / 2277-4343.05243$

ABSTRACT

Typhoid fever is a systemic infection caused by Salmonella typhi, which remains a serious problem in developing country. The traditional Vaidya belonging to various tribes are using folk medicine to prevent and cure the various diseases including Typhoid. The herbs used for Typhoid from various national-international journals and discussed. Most of the mentioned herbs have Katu-Tikta Rasa, Krimighna and Jvaragna property which help to displace or kill the microbe by Prakriti Vighat by decreasing Kapha and Malas on which these microorganisms lodges, flourish, grows and increase in numbers, thus leading to disease. Most of the mentioned folk herbs used for Typhoid have significant result in vitro and in vivo antimicrobial activity as well as clinical efficacy and also justified the concept of Ayurveda. Hence it can be stated that Typhoid can be treated by giving herbal drug which is already in use by traditional Vaidya and tribes in India, though there is further need of documentation for experimental and clinical study.
\end{abstract}

Keyword: Typhoid, enteric fever, folk medicine, herb

\section{INTRODUCTION}

Typhoid fever is a systemic infection caused by the bacterium Salmonella enterica subspecies enterica serotype typhi, which is acquired by ingestion of contaminated food and water. In 2010, there were an estimated 13.5 million typhoid fever episodes globally, while in 2000 typhoid fever caused an estimated 21.7 million illnesses and 217,000 deaths, and paratyphoid fever caused an estimated 5.4 million illnesses worldwide $^{1}$. In India 1084885 case were reported out of which 440 had died due to Typhoid ${ }^{2}$. Folk Medicine is a part of traditional medicine and there are many traditional vaidya belonging to various tribes who are giving folk medicine to cure the various diseases including Typhoid. India is a treasure of traditional knowledge and medicinal herb and traditional vaidya are using this to prevent and cure Typhoid, but scientific literature is scattered and it's need of time to evaluate it scientifically.

\section{Typhoid}

Typhoid fever is a systemic disease characterized by fever and abdominal pain caused by dissemination of $S$. typhi or $S$. paratyphi. It mainly spreads when people eat food or drink water which is already been infected with Salmonella typhi. These bacteria live only in humans. Persons with typhoid fever carry the bacteria in their bloodstream and intestinal tract.

\section{Clinical Feature of Typhoid}

The most prominent symptom of this systemic infection is prolonged fever $\left(38.8\right.$ to $40.5^{\circ} \mathrm{C}$, or 101.8 to $\left.104.9^{0} \mathrm{~F}\right)$. A prodrome of nonspecific symptoms often precedes fever and includes chills, headache, anorexia, cough, weakness, sore throat, dizziness, and muscle pains. Gastrointestinal symptoms are quite variable. Patients can be presented with either diarrhoea or constipation. Early physical findings of enteric fever include rash ("rose spots"), hepato-splenomegaly, epistaxis, and relative bradycardia. Rose spots make up a faint, salmon-coloured, blanching, maculopapular rash located primarily on the trunk and chest.

\section{Ayurvedic Aspect of Typhoid}

Gananath Sen mentioned the Antrik Jwar caused due to ingestion of bacterial contaminated food and water, which is spread by contaminated stool and urine. He is the first author who mentioned the Jivanu means bacteria as causative microorganism of Antrik Jwar.

\section{Folk Medicine}

The term folk medicine refers to healing practices and ideas of body physiology and health preservation known to a limited segment of the population in a culture, transmitted informally as general knowledge, and practiced or applied by anyone in the culture having prior experience. Folk medicine may also be referred to as Traditional medicine, Alternative medicine, Indigenous medicine, Complementary medicine, Natural medicine. In fact, out of these terms perhaps only indigenous medicine and Traditional medicine are the terms well congruent with folk medicine ${ }^{3}$. Folk medicine is the mixture of traditional healing practices and beliefs that involve herbal medicine, spirituality and manual therapies or exercises in order to diagnose treat or prevent an ailment or illness. The World Health Organization states that it is mostly practiced by indigenous or native populations and as much as $80 \%$ of the population in certain countries within Asia and Africa rely on it for primary care ${ }^{4}$. 
Table 1: Folk Medicine for Typhoid used in India

\begin{tabular}{|c|c|c|c|c|}
\hline S. No. & Herb & Family Name & Vernacular Name & Part Used \\
\hline 1 & Abrus precatorious & Fabaceae & Gunja & Seed \\
\hline 2 & Achyranthes aspera & Amaranthaceae & Apamarga & Root, Leaf \\
\hline 3 & Actiniopteris dichotoma & Actiniopteridaceae & Mayurshikha & Whole plant \\
\hline 4 & Aerva lanata & Amaranthaceae & Gorakshaganja & Leaves, Whole Plant \\
\hline 5 & Ailanthus excels & Simaroubaceae & Aralu & Stem Bark \\
\hline 6 & Aloe vera & Liliaceae & Kumari & Whole Plant \\
\hline 7 & Ammannia baccifera & Lythraceae & Agnigarba & Leaf Juice \\
\hline 8 & Aspargus racemosus & Liliaceae & Satavari & Root Extract \\
\hline 9 & Blechnum orientale & Blechnaceae & Centipede Fern & Rhizome \\
\hline 10 & Berberis aristata & Berberidaceae & Daruharidra & Whole Plant \\
\hline 11 & Boerhavia difusa & Nyctaginaceae & Punarnava & Root Juice \\
\hline 12 & Buchanania lanzan & Anacardiaceae & Priyala & Decoction of Bark \\
\hline 13 & Calligonum polygonoides & Polygonaceae & phog & Plant Extract \\
\hline 14 & Clerodendrum seratum & Verbenaceae & Bharngi & Leaf \\
\hline 15 & Corallocarpus epigaeus & Cucurbitaceae & Patalagaruda & Root \\
\hline 16 & Cassia tora & Caesalpiniaceae & Cakramarda & Root \\
\hline 17 & Cymbopogon martinii & Poaceae & Dhyamakah & Smoke of Inflorescence \\
\hline 18 & Desmodium gangeticum & Fabaceae & Shaliparni & Root \\
\hline 19 & Drynaria quercifolia & Polypodiaceae & Oak-leaf fern & Whole Plant, Rhyzome, \\
\hline 20 & Eranthemum roseum & Acanthaceae & Dashnuli & Root \\
\hline 21 & Echinops echinatus & Asteraceae & Brahmadandi & Root Powder \\
\hline 22 & Ficus racemosa & Moraceae & Udumbara & Latex Raw \\
\hline 23 & Glossocardia bosvallia & Asteraceae & Parpata & Plant Extract \\
\hline 24 & Hodgsoniam acrocarpa & Cucurbitaceae & Hati-kerela & Root and Seed \\
\hline 25 & Holiotropium indicum & Boraginaceae & Indian Heliotrope & Whole Plant \\
\hline 26 & Jatropha gossypifolia & Euphorbiaceae & Ratanjoti & Latex \\
\hline 27 & Leptadenia reticulate & Asclepiadaceae & Caksusya & Leaves Raw \\
\hline 28 & Leucas aspera & Lamiaceae & Dronapuspi & Whole Plant \\
\hline 29 & Morinda pubescens & Rubiaceae & Nagkura & Bark Decoction \\
\hline 30 & Moringa oleifera & Moringaceae & Shigru & Stem Bark \\
\hline 31 & Ocimum sanctum & Labiatae & Tulasi & Leaves \\
\hline 32 & Ruta graveolens & Rutaceae & Sudapa & Leaf Powder \\
\hline 33 & Ricinus communis & Euphorbiaceae & Eranda & Seed \\
\hline 34 & Spilanthu sacmella & Compositeae & Akarkara & Leaf \\
\hline 35 & Tephrosia villosa & Leguminosae & Sharapunkhan & Root paste \\
\hline 36 & Tinospora cardifolia & Menispermaceae & Guduci & Juice with Sugar \\
\hline 37 & Vitex peduncularis & Verbenaceae & Boruna & \\
\hline 38 & viscum monica & Santalaceae & & \\
\hline
\end{tabular}

Abrus precatorious seed powder is given in Amarantak Region Madhya Pradesh, India for treatment of Typhoid ${ }^{5}$. Antimicrobial study show Gujna exhibited significant antimicrobial activities against Salmonella typhi ${ }^{6}$. Achyranthes aspera root decoction is given in Shekhavati Rajsthan ${ }^{7}$ and Leaf $10 \mathrm{~g}$ with 7 black pepper seed in Orissa $^{8}$ to cure Typhoid. Extracts in organic solvents of Achyranthes aspera but neither the leaf nor stem parts of A. Aspera in any organic extractions showed antibacterial activity ${ }^{9}$. Whole plant of Actiniopteris dichotoma is used in Rajsthan ${ }^{10}$. Aerva lanata leaves extract 1 teaspoon full twice a day for 3 day orally given in Buldhana district

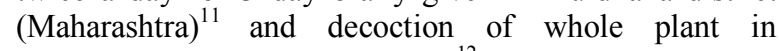
Shekhawati Region Rajasthan ${ }^{12}$ to cure Typhoid. Ailanthus excels stem bark extract is given by Bhil Tribes of Bibdod Madhya Pradesh, India ${ }^{13}$. Aloe vera whole plant is used in Eastern Ghat of Koli Hill Tamil Nadu, India for the treatment of Typhoid ${ }^{14}$. The study revitalizes the traditional system of medicine in order to achieve selfreliance in health care and health for all by analysing the antimicrobial property of aqueous extracts of Aloe vera and to assess the reason for inhibition of growth of pathogenic organisms by DNA and protein analysis. Various aqueous extracts showed inhibition to microorganisms Salmonella typhi ${ }^{15}$. Leaf juice of Ammannia baccifera with honey is given empty stomach in south Orissa ${ }^{16}$. The ethanolic extract of leaf of $A$. baccifera exhibited highest and lowest $(22.0 \pm 0.8$ and $10.9 \pm 0.11 \mathrm{~mm}$ ) inhibition against $S$. typhi and $S$. aureus, respectively. $S$. typhi was also strongly inhibited (18.5 \pm $0.27 \mathrm{~mm})$ whereas $E$. coli inhibited poorly $(10.1 \pm 0.13$ $\mathrm{mm}$ ) by its root extract ${ }^{17}$. Bhil Tribes of Bibdod Madhya Pradesh, India uses root extract of Aspargus racemosus ${ }^{18}$. Methanolic extract of Aspargus racemosus particularly at concentration of $1 \mu \mathrm{g} / \mu \mathrm{l}$ was found to be effective against all bacterial strains including Salmonella typhi ${ }^{19}$. Blechnum orientale rhizome used in Western Ghat, Himalaya, Tripura, and Orissa and Western Ghats of Maharashtra, India ${ }^{20,21}$. The antimicrobial property in the extracts of Blechnum orientale has been evaluated on clinically isolated bacterial pathogens, aqueous extract showed relatively higher zone of inhibition against $S$. typhi $i^{22}$. Entire Plant of Berberis arishtata is used in Belgaum district karntaka, India ${ }^{23}$. The aqueous and methanol extracts from the studied plants including Berberis arishtata showed broad range of activity and could be potential source of antimicrobial compounds ${ }^{24}$. Bhils and its Sub tribes give Boerhavia difusa root Juice 5 $\mathrm{g}$ twice a day for 7 days orally with Ghee ${ }^{25}$. Among the three extracts methanol crude extract of aerial part of plant of Boerhavia difusa exhibited strong antibacterial activity compared to petroleum ether extract and 
chloroform extract ${ }^{26}$. Tribals of Kinwat Forest Maharashtra, India gives bark decoction of Buchanania lanzan twice a day for 3 day ${ }^{27}$. Methanol extracts of Acacia caesia (bark), Dillenia pentagyna (bark) and Buchanania lanzan (bark) screened for antimicrobial potential against seven bacterial species including Salmonella $s p$. and $B$. lanzan showed highest zone of inhibition $^{28}$. Plant extract of Calligonum polygonoides is used in Shekhawati Region Rajsthan, India ${ }^{29}$. The tribes of Khammam Andra Pradesh, India use Clerodendrum seratum leaf for enteric fever ${ }^{30}$. Meena community in Rajasthan, India uses root of Corallocarpus epigaeus for Typhoid $^{31}$. Root paste of Cassia tora and along with the powder prepared from the horn of a cow is used as traditional medicine for Typhoid in Rajsthan, India ${ }^{32}$. Ethanolic extract $(0.15 \mathrm{mg})$ and aqueous extract $(0.31 \mathrm{mg})$ of Cassia tora showed antibacterial activity against all tested bacteria but maximum activity were showed by aqueous extract against Staphylococcus aureus and Lactobacillus. But aqueous extract did not showed any activity against Salmonella typhi ${ }^{33}$. Bhils and its Sub tribes use smoke of Inflorescence of Cymbopogon martini to treat the enteric fever ${ }^{34}$. The essential oil and extract of C. martini have significant antimicrobial activity on $S$. typhi ${ }^{35}$. Desmodium gangeticum root extract ${ }^{36}$ and root paste with Long Pepper is used in Purulia District West Bangal, India ${ }^{37}$. The methonalic extract of $D$. gangeticum be able to use as potential antibacterial source for various infective pathogens including $S$. typhi ${ }^{38}$. Dry Naria quercifolia plant decoction is used in Western Ghat ${ }^{39}$ and Arunachal Pradesh, India ${ }^{40}$, while rhyzome are used in Wayanadu district of Kerala, India ${ }^{41}$ and whole plant in Western Ghat, Tripura Orissa, India ${ }^{42}$. Ethanolic and methanolic extracts of rhizome of $D$. quercifolia showed high efficiency of antibacterial activity and gram-negative bacteria were more susceptible to all the extracts tested ${ }^{43}$. Bhils and its Sub tribes give Eranthemum roseum root ground with glassful of water $1 / 6$ glass twice a day for 3 days orally ${ }^{44}$. Antimicrobial activity of the roots of Eranthemum roseum (Vahl) R.Br. (Dasmuli), were tested against different bacteria including Salmonella typhi, showed strong activity of the petroleum ether extract of the roots of plant against the bacteria ${ }^{45}$; Echinops echinatus root powder 1 tablespoonful, once a day at morning for 21 days orally is used in Buldhana District Maharashtra, India ${ }^{46}$. The mother tinctures of desert were screened for antibacterial activity against bacterial strains of Gram-positive and Gram-negative bacteria. Echinops echinatus mother tincture showed highly effectiveness only against Salmonella typhi ${ }^{47}$. Bhils and its Sub tribes give raw latex of Ficus racemosa $1 / 4$ table spoonful once a day orally ${ }^{48}$. Ethanolic extracts of 7 plants including $F$. racemosa showed antibacterial activity against $S$. typhimurium $^{49}$. In another shudy the presence of wide spectrum of antibacterial activities against all the above bacterial pathogens studied. The maximum zone of inhibition observed for each bacterium was as follows: $S$. typhi $(12 \mathrm{~mm})^{50}$. Tribals of Kinwat Forest Maharashtra, India give spoonful extract of Glossocardia bosvallia plant with cow milk twice a day ${ }^{51}$. The Naga Tribes give root and seed of Hodgsonia macrocarpa for Typhoid ${ }^{52}$. Whole plant of Holiotropium indicum is given in primary health care Karnataka, India to treat Typhoid ${ }^{53}$. The carbon tetrachloride soluble materials of $H$. indicum demonstrated activity against $S$. typhi with zone of inhibition $7.0 \pm 0.73^{54}$. Tribals of Kinwat Forest Maharashtra, India give Jatropha gossypifolia 12 drops of latex mixed with $100 \mathrm{~g}$ of Jaggery thrice a day for 3 days ${ }^{55}$. The extracts of 24 plants including Jatropha gossypifolia showed anti-microbial activity in a range of $75-1200 \mu \mathrm{g} / \mathrm{ml}^{56}$. Bhils and its Sub tribes 4-5 leaves of give Leptadenia reticulate thrice a day orally ${ }^{57}$. Amongst the tested three extracts, chloroform extract showed high antimicrobial activity against $E$. coli, alcoholic extract showed high antibacterial activity against Pseudomonas aeruginosa, while petroleum ether extract showed antibacterial activity against Klebsilla pneumonae, but no antimicrobial activity of $J$. gossypifolia has seen against $S$. typhi $i^{58}$. Whole plant of Leuca saspera is given in Nilgiri Biosphere Reserve ${ }^{59}$. Methanol extract of $L$. aspera showed stronger activity compared to ethyl acetate and petroleum ether extracts. It showed highest activity against Pseudomonas aeruginosa with zone of inhibition of $15 \mathrm{~mm}$. The standard chloramphenicol did not show any activity against Shigella sonnei. But all the extracts showed moderate activity against this pathogen with zone of inhibition ranging from 10 to $13 \mathrm{~mm}^{60}$. In another study significant $(\mathrm{P}<0.05)$ zone of inhibitions against Gram positive and Gram negative Salmonella typhi, Salmonella paratyphi was observed ${ }^{61}$. Tribes of Kinvat Forest of Nanded District, Maharashtra, India uses bark decoction of Morinda pubescens 2 table spoonful thrice a day for 3 day $^{62}$. Bhils and its Sub tribes give Stem Bark Decoction of Moringa oleifera 2 table spoonful once a day orally ${ }^{63}$. The fruit extract of Moringa oleifera showed a broad-spectrum antibacterial activity with a zone of inhibition of Salmonella typhi range from 11-15 $\mathrm{mm}^{64}$. In another study the ethanolic extract was active against Salmonella typhi and Staphylococcus aureus whereas the aqueous extract exhibited an inhibitory effect on Staphylococcus aureus only ${ }^{65}$. Vaidyas in Uttaranchal India uses Ocimum sanctum leaves Juice and Pudina leaves with $5 \mathrm{~g}_{\text {sugar }}{ }^{66}$. The antibacterial results showed methanol extracts $(0.4 \mathrm{~g} / \mathrm{ml})$ of Ocimum gratissimum and Ocimum sanctum showed maximum zone of inhibition (30 $\mathrm{mm}$ and $25.5 \mathrm{~mm}$, respectively) against Salmonella typhi $i^{67}$. In vitro and in vivo study, among all the extracts methanolic extracts of both the plants had stronger antibacterial activity. On prolonged incubation bacterial colonies reappeared within the zone of inhibition indicating bacteriostatic effect than bactericidal activity. $250 \mathrm{mg} / \mathrm{kg}$ body weight oral dose of $O$. sanctum and $A$. mexicana was found ideal and nontoxic in chickens and experimental chickens were fed this dose for 21 days for determination of in vivo antibacterial effect. On $22^{\text {nd }}$ day respective groups of chickens were challenged orally with $\mathrm{ID}_{50}$ dose of Salmonella enteric, Serovar typhimurium and Escherichia coli. $83 \%$ chickens of OS fed groups and 66 $\%$ chickens of AM fed groups were protected from challenge of $S$. enterica Serovar typhimurium and E. coli. $O$. sanctum provided better clearance of both the pathogens from blood as compared to $A$. mexicana ${ }^{68}$. Ruta graveolens leaf powder with a cup of hot water is given in Bhadravati Taluka Shimoga District Karnataka, India ${ }^{69}$. 
The ethanolic stem extract of $R$. graveolens showed pronounced inhibition of growth than other extracts. The ethanolic extract showed most susceptible activity against $S$. aureous and $B$. subtilis where as $P$. aeruginosa was the most resistant bacteria strain ${ }^{70}$. Ricinus communis seed is used in Eastern Ghat of Koli Hill Tamil Nadu, India ${ }^{71}$. Antimicrobial test with eleven bacteria demonstrated that the extracts of cell suspension culture of $R$. communis L. cv. Roktima holds the merit of antimicrobial activity and it was considered to be the potent source of antibacterial compounds $^{72}$. Gond Tribe in Bhandara District Maharashtra, India uses Spilanthus acmella leaf ${ }^{73}$. The Kandhas of Kandhamal District of Orissa, India uses Tephrosia villosa root paste with raw milk for 7 day $^{74}$. Tribes in Satpuda region of Dhule and Jalgaon (Maharashtra), India uses Tinospora cardifolia juice with sugar $^{75}$. The methanolic extract of $T$. cardifolia plant was found to have antimicrobial activity against Bacillus subtilis, E coli, Staphylococcus aureus and Salmonella typhi $^{76}$. The tribals of Ajoydha Hill Region, Purulia District West Bengal, India use Vitex peduncularis in Typhoid $^{77}$. The results of antibacterial activity of vitex species showed that the extracts possessed a broad spectrum of antibacterial activity. The $V$. peduncularis possessed the highest activity against all the microorganisms screened $^{78}$. The tribes of Kerala use Viscum monica for the treatment of enteric fever ${ }^{79}$.

\section{DISCUSSION}

Folk medicine is used all over India by Traditional practiser or Tribes for enteric fever, but generally practice of folk medicine found in rural, tribal and backward region. Though all the parts are used to treat the typhoid, but root, stem bark and whole plant are used frequently in mentioned folk medicine. None of the family have dominant in the management of such fever. Maximum plants which are given by Traditional practiser or Tribes for enteric fever have significant anti-microbial activity including $S$. typhi. Most of the plants have alkaloid as a major chemical constituent and active principle. Alkaloids have an anti-microbial property which helps to act as a bactericidal or bacteriostatic action. But alkaloids from bitter plant have more intense anti-microbial activity than other. Acharya Charak has also stated that Tikta Rasatmak Dravya (Bitter Drugs) is acts as a Krimighna (anti-microbial) along with Jvaraghna (anti-pyretic) ${ }^{80}$. Even most of the herbs mentioned by Charak for Vishama Jwar have bitter property ${ }^{81}$. The maximum plants are used by Traditional Vaidyas or Tribes having also Tikta Rasa and krimighna in property which help to kill or displace the S. typhi. Charak described the Prakriti Vighata that uses the drugs which stops growth of pathogenic microbes by producing an unfavourable condition for microorganisms to growth. Drugs having Katu, Tikta, Kshra (alkali), Ushna (worm material) properties decreases the Kapha and Malas on which these microorganisms abide, germinate, reproduce and increase colony causing pathology. Thus Herbs or Drugs having these properties help to kill and remove the bacteria and its toxin causes early recovery from infective pathology including Typhoid.

\section{CONCLUSION}

Most of the mentioned folk herbs used for Typhoid have significant result in vitro and vivo anti-microbial activity as well as clinical efficacy and also justify the concept of Ayurveda. Hence it can be stated that Typhoid can be treated by giving herbal drug which is already used by Traditional Vaidya and Tribes in India, though there is further need of documentation by experimental and clinical study on large scale to give validity.

\section{REFERENCES}

1. John A. Crump and Eric D. Mintz 'Global Trends in Typhoid and Paratyphoid Fever’ Emerging Infections, CID 2010; 50: 241-416.

2. Health Status Indicator http://cbhidghs.nic.in/writereaddata/ mainlinkFile/08\%20Health\%20Status $\% 20 \% 20$ Indicators $\% 20 \% 202$ 011.pdf

3. Definition of folk Medicine, http://en.wikipedia.org/wiki/ Folk_medicine.

4. Folk Medicine and Traditional Healing, http://www.ncfh.org/docs/ fs-Folk\%20Medicine.pdf.

5. Anupam Shrivastav, Shambhu $P$ Patel, Rajesh K Mishra. Ethnomedicinal Importance of the Plants of Amarantak Region Madhya Pradesh India' Int. J. Med. Arom. Plants 2012; 2(1): 53-59.

6. GEK Bolou, I Bagré, K Ouattara and AJ Djaman. Evaluation of the Antibacterial Activity of 14 Medicinal Plants in Côte d'Ivoire' Tropical Journal of Pharmaceutical Research 2011; 10(3): 335-340. http://dx.doi.org/10.4314/tjpr.v10i3.3

7. SS Katewa, PK Galav. Addition to the Folk Herbal Medicines from Shekhawati Region Rajsthan. Indian Journal of Traditional Knowledge 2006; 5(4): 494-500.

8. Soumit K Behera, Anima Panda, Sushant K Behera. Medicinal Plant used by the Kandhas of Kandhamal District of Orissa' Indian Journal of Traditional Knowledge 2006; 5(4): 519-528.

9. MT Alam, MM Karimand, Shakila N Khan. Antibacterial Activity of Different Organic Extracts of Achyranthes aspera and Cassia alata' J. Sci. Res 2009; 1(2): 393-398.

10. Ajay Kumar Meena, MM Rao. Folk herbal medicines used by the Meena community in Rajasthan. Asian Journal of Traditional Medicines 2010; 5(1).

11. PS Patil, YA Ahirrao, UP Aher, DA Patil. Role of Crop Weeds in Traditional Medicines in Buldhana Distric Maharashtra' Life Science Leaflet 2010; 10: 261-272.

12. S Katewa, PK Galav. Traditional Herbal Medicines from Shekhawati Region Rajsthan' Indian Journal of Traditional Knowledge 2005; 4(3): 237-247.

13. Dinesh Jadhav. Ethnomedicinal Plant used by Bhil Tribes of Bibdod Madhya Pradesh' Indian Journal of Traditional Knowledge 2006; 5(2): 263-267.

14. Prabhu M, Kummuthakallavali R. Folk Remedy for Medicinal Plant for Snake Bite, Scorpion Sting and Dog Bite in Eastern Ghat of Koli Hill Tamil Nadu. Int. J. Res. Ayur. Pharm 2012; 3(5): 696-700. http://dx.doi.org/10.7897/2277-4343.03523

15. Jeswin Philip, Sheila John and Priyalyer. Antimicrobial Activity of Aloe vera barbedensis, Daucus carota, Emblica officinalis, Honey and Punica granatum and Formulation of a Health Drink and Salad. Malaysian Journal of Microbiology 2012; 8(3): 141-147.

16. Anima Panda and Malaya Mishra. Ethno medicinal Survey of Some Wetland Plants of South Orissa and there Conservation. Indian Journal of Traditional Knowledge 2011; 10(2): 296-303.

17. Sahoo S, Nayak D, Kumar GS and Jayakumari S. Antimicrobial Investigation of Ammania baccifera Linn. Against some Urinary and Gastro-Intestinal Tract Infection Causing Pathogens. Indian Drugs 2012; 49(12).

18. Dinesh Jadhav. Ethnomedicinal Plant used by Bhil Tribes of Bibdod Madhya Pradesh. Indian Journal of Traditional Knolledge 2006; 5(2): 263-267.

19. Mukhtair Uddin, Muhammad Asad Ghufran, Muhammad Idrees, Muhammad Irshad. Antibacterial Activity of Methanolic Root Extract of Asparagus racemosus. Journal of Public Health and Biological Sciences 2012; 1(2): 32-35.

20. Pratibha Kumari, AM Otaghvari. Some Ethno-Medicinally Impartant Pteridophyte of India Published in Int. J.M. Aromatic Plant 2011; 1(1): 18-22.

21. Sachin Patil, VP Masal and Meena Dongare. In the Search of Ethano-Medicinal Pteridophytes from Western Ghats of 
Maharashtra (India) https://www.google.co.in/url?sa=tandrct= jandq $=$ andesrc $=$ sandsource $=$ webandcd $=1$ andcad $=$ rjaandved $=0$ CCsQ FjAAandurl=http $\% 3 \mathrm{~A} \% 2 \mathrm{~F} \% 2 \mathrm{Fwww}$.researchgate.net $\% 2 \mathrm{Fpublicati}$ on $\% 2$ F255992464Downloaded on 3/10/13

22. J Deepa, TR Parashurama, $M$ Krishnappa and $S$ Nataraja. Antimicrobial Efficacy of Blechnum orientale L. Int J Pharm Bio Sci 2013; 4(2): 475-479.

23. Jyoti S Kawalekar. Medicinal plants used by local vaidyas in Gavanal village, at Hukkeri Taluk, Belgaum district' International Journal of Phytothearpy Research, www.earthjournal.org

24. Anjum Gahlaut and Anil K Chhillar. Evaluation of Antibacterial Potential of Plant Extracts Using Resazurin Based Microtiter Dilution Assay. Int J Pharm Pharm Sci 5(2): 372-376.

25. Swati Samvatsar, Samaj Pragati Sahyog. Plant used for the different type of Fever by Bhilsand its Sub tribes in India' Indian Journal of Traditional Knowledge 2004; 3(1): 96-100.

26. YL Ramachandra, $\mathrm{C}$ Ashajyothi and $\mathrm{S}$ Padmalatha Rai. In vitro Antibacterial Potential of Boerhaavia diffusa. IJAPBC 2012; 1(3): 420-423.

27. SD Biradarand, DP Ghoraband. Ethnomedicinal Wisdom of Tribals of Kinwat Forest Maharashtra, Indian J. of Natural Products and Resources 2010; 1(2): 254-257.

28. Venkata Smitha P, Murali Mohan Ch, Prameela Kandra, Sravani R and Raju B Akondi Screening of Antimicrobial and Antioxidant Potentials of Acacia caesia, Dillenia pentagyna and Buchanania lanzan from Maredumilli Forest of India' Journal of Pharmacy Research 2012; 5(3): 1734-1738.

29. SS Katewa, PK Galav. Traditional Herbal Medicines from Shekhawati Region Rajsthan, Indian Journal of Traditional Knowledge 2005; 4(3): 237-247.

30. Rajendra P Gujjeti, Estari Mamidala. Ethno Botanical Survey of Medicinal Plants Used by the tribes of Khammam Andra Pradesh India' Journal of Research in Plant Sciences 2012; 1(2): 132-137.

31. Ajay Kumar Meena, MM Rao. Folk herbal medicines used by the Meena community in Rajasthan' Asian Journal of Traditional Medicines 2010; 5(1).

32. Meghendra Sharma and Ashwani Kumar. Traditional Medicinal Plants of Rajasthan Used In Tribal Medicine: A Review' International Journal of Life Science and Pharma Research 2013; $3(2)$.

33. RT Chavan, VL Deshmukh and AS Kadam. Antibacterial Activity of Cassia tora Leaves' Rec Res Sci Tech 2011; 3: 12-14.

34. Swati Samvatsar, Samaj Pragati Sahyog. Plant used for the different type of Fever by Bhilsand its Sub tribes in India' Indian Journal of Traditional Knowledge 2004; 3(1): 96-100.

35. KA Hammer, CF Carson and TV Riley. Antimicrobial activity of essential oils and other plant extracts' Journal of Applied Microbiology 1999; 86: 985-990. http://dx.doi.org/10.1046/j.13652672.1999.00780.x

36. Maurya Umashanker and Srivastava Shruti. Traditional Indian Herbal Medicine Used as Antipyretic, Antiulcer, Anti-Diabetic and Anticancer: A Review' International Journal of Research in Pharmacy and Chemistry 2011; 1(4).

37. MK Chakrabothy, A Bhattacharjee. Some Common ethnomedicinal uses for various diseases Purulia District West Bangal' Indian Journal of Traditional Knowledge 2006; 5(4): 554-558.

38. Krishnasamy Karthikeyan, Gandhi Siddhar Selvam, Rajendran Srinivasan, Chidambaram Chandran and Subramaniyan Kulothungan 'In vitro antibacterial activity of Desmodium gangeticum (L.) DG' Asian Pacific Journal of Tropical Disease 2012; S421-S424.

39. Benjamin A and Manickam VS. Medicinal Pteridophytes from Western Ghat' Indian Journal of Traditional Knowledge 2007; 6(4): 611-618.

40. Binniamin A. Medicinal Ferns of North India with special reference to Arunachal Pradesh' Indian Journal of Traditional Knowledge $2011 ; 10(3): 516-522$.

41. Francis Xavier T, Arun VR and Freeda Rose A. Ethnopharmacological studies on the medicinal plants used by tribal inhabitants of meenagadi region in wayanadu district of Kerala, South India' Int. J. Med. Plants. Res 2012; 1(5): 058-062.

42. Pratibha Kumari, AM Otaghvari. Some Ethno-Medicinally Important Pteridophyte of India' Int. J.M. Aromatic Plant 2011; 1(1): 18-22.

43. M Kandhasamy, KD Arunachalam and AJ Thatheyus. Drynaria quercifolia (L.) J. Sm: A potential resource for antibacterial activity' Afr. J. Microbiol. Res 2008; 2: 202-205.
44. Swati Samvatsar, Samaj Pragati Sahyog. Plant Used for the different type of Fever by Bhils and its Sub tribes in India' Indian Journal of Traditional Knowledge 2004; 3(1): 96-100.

45. Ashish S Jain, Sanjay J Surana, SB Gokhale, Anil U Tatiya and Rupail C Bothara. Antimicrobial Properties of Eranthemum roseum (Vahl) R.Br.' International Journal of Production Research 2007; 6(2): 131-133

46. PS Patil, YA Ahirrao, UP Aher, DA Patil. Role of Crop Weeds in Traditional Medicines in Buldhana Distric Maharashtra' Life Science Leaflet 2010; 10: 261-272.

47. M Ahmad, Nazia Ghafoor and MN Aamir. Antibacterial Activity of Mother Tinctures of Cholistan Desert Plants in Pakistan' Indian Journal of Pharmaceutical Sciences 2012; 465-468.

48. Swati Samvatsar, Samaj Pragati Sahyog. Plant Used for the different type of Fever by Bhils and its Sub tribes in India' Indian Journal of Traditional Knowledge 2004; 3(1): 96-100.

49. Rathish NAIR, Sumitra V Chanda. Antibacterial Activities of Some Medicinal Plants of the Western Region of India' Turk J Biol 2007; 31: 231-236.

50. Renisheya Joy Jeba Malar T, Johnson M, Mary Uthith M, Arthy A. Antibacterial activity of ethanolic extracts of selected medicinal plants against human pathogens' Asian Pacific Journal of Tropical Biomedicine 2011; S76-S78.

51. SD Biradar and DP Ghoraband. Ethnomedicinal Wisdom of Tribals of Kinwat Forest Maharashtra' Indian J. of Natural Products and Resources 2010; 1(2): 254-257.

52. NS Jamir, Lanusunep and Narola Pongener. Medico-Herbal Medicine Practiced by the Naga Tribes in the State of Nagaland (India), Indian Journal of Fundamental and Applied Life Sciences 2012; 2(2): 328-333.

53. Siddamallaya N, Azra Asmeen and K Gopakumar. Hundred Common Forest Medicinal Plant of Karnataka in Primary Health care' Indian Journal of Traditional Knowledge 2010; 9(1): 90-95.

54. Nusrat Ahmed Mourin, Tasnuva Sharmin, Sharmin Reza Chowdhury. Evaluation of bioactivities of Heliotropium indicum, a medicinal plant of Bangladesh' The Pharma Innovation - Journal 2013; 2(5): 217-221.

55. SD Biradarand DP Ghoraband. Ethnomedicinal Wisdom of Tribals of Kinwat Forest Maharashtra' Indian J. of Natural Products and Resources 2010; 1(2): 254-257.

56. Rajesh Dabur, Amita Gupta, TK Mandal, Desh Deepak Singh, Vivek Bajpai and AM Gurav. Antimicrobial Activity of Some Indian Medicinal Plants' Afr. J. Trad. CAM 2007; 4(3): 313-318.

57. Swati Samvatsar, Samaj Pragati Sahyog. Plant used for the different type of Fever by Bhilsand its Sub tribes in India' Indian Journal of Traditional Knowledge 2004; 3(1): 96-100.

58. Kalidass C, Glory M, Francis Borgio and Manickam VS Antibacterial Activity of Leptadenia reticulata (Retz.) Wight. And Arn. (Asclepidaceae), http://www.avpayurveda.com/ dmdocuments/ AMJ\%2009\%20-\%203.pdf

59. Pradheeps M and G Poyyamoli. Ethnobotany and utilization of plant resources in Irula villages (Sigur plateau, Nilgiri Biosphere Reserve, India' Journal of Medicinal Plants Research 2013; 7(6): 267-276.

60. M Akter, MAI Khan, MDA Muhsin, K Hamid, M Obayed Ullah. In vitro studies on antibacterial, antifungal, and cytotoxic properties of Leucas aspera' Biology and Medicine 2012; 4(4): 183-187.

61. Md Atiar Rahman and Md Saiful Islam. Antioxidant, antibacterial and cytotoxic effects of the phytochemicals of whole Leucas aspera extract' Asian Pac J Trop Biomed 2013; 3(4): 273-279. http://dx.doi.org/10.1016/S2221-1691(13)60062-3

62. Dnyaneshwar P Ghorband, Sharad D Biradar. Folk Medicine Used by the Tribes of Kinvat Forest of Nanded District, Maharashtra India' Indian Journal of Natural Product and Resources 2012; 3(1): 118-122

63. Swati Samvatsar, Samaj Pragati Sahyog. Plant Used for the different type of Fever by Bhils and its Sub tribes in India' Indian Journal of Traditional Knowledge 2004; 3(1): 96-100.

64. Mohammed Abu Sayeed, Mohammad Shahadat Hossain, Mohammad Ehsanul Hoque Chowdhury and Mohsinul Haque. In Vitro Antimicrobial Activity Of Methanolic Extract of Moringa olieifera Lam. Fruits' Journal of Pharmacognosy and Phytochemistry 2012; 1(4): 94-98.

65. B Vinoth, $\mathrm{R}$ Manivasagaperumal and $\mathrm{S}$ Balamurugan. Phytochemical Analysis and Antibacterial Activity of Moringa oleifera Lam. International Journal of Research in Biological Sciences 2012; 2(3): 98-102. 
66. Chandraprakash Kala, Nehal Farooqueand BS Majila. Indigenous knowledge and Medicinal Plants used by vaidyas in Uttaranchal India' Natural Product Radiance 2005; 4(3): 195-206.

67. N Prasannabalaji, G Muralitharan, RN Sivanandan, S Kumaran and SR Pugazhvendan Antibacterial activities of some Indian traditional plant extracts' Asian Pacific Journal of Tropical Disease 2012; S291-S295.

68. $\mathrm{P}$ Varshney, SK Dash, AK Bhatia. In vitro and in vivo Antibacterial Effects of Leaf Extracts of Ocimum sanctum and Argemone mexicana' Medicinal Plant Research 2013; 3(9): 63-69.

69. MB Shivanna and N Rajkumar. Ethno medico Botanical Knowledge of Rural Folk of Bhadravati Taluka Shimoga District Karnataka' Indian Journal of Traditional Knowledge 2010; 9(1): 158-162.

70. Pinkee Pandey, Archana Mehta, Subhadip Hajra. Evaluation of Antimicrobial Activity of Ruta graveolens Stem Extracts by Disc Diffusion Method' Journal of Phytology 2011; 3(3): 92-95.

71. Prabhu M, Kummuthakallavali. Folk Remedy for Medicinal Plant for Snake Bite, Scorpion Sting and Dog Bite in Eastern Ghat of Koli Hill Tamil Nadu' Int. J. Res. Ayur. Pharm 2012; 3(5): 696-700. http://dx.doi.org/10.7897/2277-4343.03523

72. MA Rahman and MA Bari. Antibacterial Activity of Cell Suspension Cultures of Castor (Ricinus communis L. Cv. Roktima)' http://www.sciencedomain.org/uploads/1370580541-8-Revisedmanuscript version2.pdf

73. Rakhi Gupta, MG Vairale. Ethno medicinal Uses of Some Plants Used by Gond Tribe in Bhandara District Maharashtra' Indian Journal of Traditional Knowledge 2010; 9(4): 713-717.

74. Soumit K Behera, Anima Panda, Sushant K Behera. Medicinal Plant used by the Kandhas of Kandhamal District of Orissa' Indian Journal of Traditional Knowledge 2006; 5(4): 519-528.
75. DL Jain, AM Baheti. Use of Medicinal Plants among tribes in Satpuda region of Dhule and Jalgaon District of maharashtra- An Ethno Botanical Survey' Indian Journal of Traditional Knowledge 2010; 9(1): 152-157.

76. Madhu Kumari. 'Evaluation of Methanolic Extracts of in vitro Grown Tinospora cordifolia (Willd) for Antibacterial Activities' Asian J Pharm Clin Res 2012; 5(3): 172-175.

77. Abhijit Dey and Dr Jitendra Nath De. A Survey of Ethnomedicinal Plants used by the tribals of Ajoydha Hill Region, Purulia District, India' American-Eurasian Journal of Sustainable Agriculture 2010; 4(3): 280-290.

78. Krishnan Kannathasan, Annadurai Senthilkumar, Venugopalan Venkatesalu. In vitro antibacterial potential of some Vitex species against human pathogenic bacteria' Asian Pacific Journal of Tropical Medicine 2011; 645-648.

79. AE Shanavasakhan, $M$ Shivdasan, Ahmed $\mathrm{H}$ Alfarahanand Jacob Thomas. Ethanomedicinal Aspect of Angiospermic Epiphyte and Paraphyte of Kerala in India' Indian Journal of Traditional Knowledge 2012; 11(2): 250-258.

80. Kashinath Shastri, Gorakhanath Chaturvedi. Charak Samhita Sutrasthan Shadarasa Prakaran 26/43-5' Chaukhamba Bharati Academy Varanasi, $14^{\text {th }}$ edition; 1988. p. 506.

81. Kashinath Shastri. Charak Samhita Chikitsasthan 3/201-203' Chaukhamba Bharati Academy Prakashana, 14 ${ }^{\text {th }}$ Edition; 1987. p. 150

\section{Cite this article as:}

Sharad Maroti Porte. Overview of folk medicine used for typhoid in India. Int. J. Res. Ayurveda Pharm. 2014;5(2):219-224 http://dx.doi. org/10.7897/2277-4343.05243 